\title{
Quantifying Landscape Degradation Following Construction of a Highway Using Landscape Metrics in Southern Iran
}

\author{
Alireza Mohammadi ${ }^{* *}$ and Faezeh Fatemizadeh ${ }^{2}$ \\ ' Department of Environmental Science and Engineering, Faculty of Natural Resources, University of Jiroft, Jiroft, Iran, \\ ${ }^{2}$ Faculty of Natural Resources, College of Agriculture and Natural Resources, University of Tehran, Tehran, Iran
}

OPEN ACCESS

Edited by:

Fraser Shilling,

University of California, Davis,

United States

Reviewed by:

Andrew Chin,

Toronto and Region Conservation

Authority, Canada

Simone R. Freitas,

Federal University of $A B C$, Brazil

${ }^{*}$ Correspondence:

Alireza Mohammadi

armohammadi1989@gmail.com

Specialty section:

This article was submitted to

Urban Ecology,

a section of the journal

Frontiers in Ecology and Evolution

Received: 06 June 2021

Accepted: 29 October 2021

Published: 06 December 2021

Citation:

Mohammadi A and

Fatemizadeh F (2021) Quantifying

Landscape Degradation Following

Construction of a Highway Using

Landscape Metrics in Southern Iran.

Front. Ecol. Evol. 9:721313.

doi: 10.3389/fevo.2021.721313
Rapid expansion of roads is among the strongest drivers of the loss and degradation of natural habitats. The goal of the present study is to quantify landscape fragmentation and degradation before and after the construction of the Isfahan-Shiraz highway in southern Iran. To this end, the ecological impacts of the highway on forests, rangelands, and protected areas were evaluated. Impacts of the construction of the highway were studied within a 1,000-m buffer around the road, which was then overlaid on maps of forests, rangelands, and protected areas. Class area, number of patches, largest patch index, edge density, landscape shape index, mean patch size, and patch cohesion index were used to gauge changes in the spatial configuration of the landscape; the ecological impacts of the highway were quantified using effective mesh size (MESH), division index, and splitting index. The results indicated that after the construction of the highway, 6,406.9 ha of forest habitat, 16,647.1 ha of rangeland habitat, and 912 of the Tang-e Bostanak Protected Area will be lost. The effective MESH metric showed that after the construction of the highway, the area of forest, rangeland habitats and protected area will decrease by $20,537,49,149$, and 71,822 ha, respectively. Our findings revealed drastic habitat loss and landscape fragmentation associated with construction of the highway, serving as references for conservation planning and development.

Keywords: habitat fragmentation, highway construction, forest, rangeland, Tang-e Bostanak Protected Area

\section{INTRODUCTION}

Over the last few decades, anthropogenic activities have substantially altered landscape structure, pattern and dynamics in response to spatial and temporal changes in land utilization (Singh et al., 2017; Kumar et al., 2018). Landscape fragmentation is to a large extent caused by infrastructural development, mining activities, reduction in forest cover, population growth, conversion of land due to agricultural expansion, etc. (Turner et al., 2003; Kumar et al., 2018; Cao et al., 2021; Feng et al., 2021). People in developing countries often depend almost entirely on natural resources to meet their basic needs (Zhao et al., 2006; Parsa et al., 2016). Therefore, sustainable land management is increasingly confronted with competition from utilization and overexploitation, which requires constant monitoring of land use and land cover changes over time (Shooshtari et al., 2012; Mansour et al., 2020; Mishra et al., 2020).

The rapid growth of the global human population coupled with accelerating economic development has led to increasing construction of road infrastructures, raising the alarm over possible impacts on the environment and habitats (Laurance et al., 2017; Ruiz and Guevara, 2020; 
Valerio et al., 2021). Roads are the most prevalent form of constructed features on Earth and can be found almost everywhere on the planet (Ibisch et al., 2016; Ascensão et al., 2021). Estimates predict that an additional 25 million $\mathrm{km}$ of roads will be constructed by 2050 , almost entirely (90\%) in developing countries (Dulac, 2013; Ascensão et al., 2021). Roads are essential to economic growth and improved quality of human life; however, these man-made features can also negatively impact wildlife by partitioning habitats and increasing wildlife mortality due to collisions with vehicles (Ali et al., 2015; Carter et al., 2020; Ascensão et al., 2021).

Roads contribute to loss of biodiversity, both directly, through habitat fragmentation and degradation (Meijer et al., 2018; Silva et al., 2020; Fullman et al., 2021), reduced movement and gene flow (Epps et al., 2005; Cushman et al., 2010; Dean et al., 2019), increased risk of wildlife vehicle collisions (Mohammadi and Kaboli, 2016; Mohammadi et al., 2018; Saint-Andrieux et al., 2020; Borowik et al., 2021) and increased disturbance (Leblond et al., 2013; Iglesias-Merchan et al., 2018), and indirectly, via providing access for poaching (Clevenger et al., 2002; Ordiz et al., 2017; Kaszta et al., 2019; Carter et al., 2020).

Landscape metrics quantitatively capture the composition and configuration of habitats in a landscape and often reflect the degree of fragmentation (McGarigal and Cushman, 2005; McGarigal et al., 2012). Landscape metrics offer insights into the different land cover and habitat types in a landscape and reveal landscape patterns and processes (Loraamm, 2011). These metrics are generally utilized to identify natural or anthropogenic changes at the level of patches, classes, or landscapes (McGarigal and Cushman, 2005).

The majority $(76 \%)$ of available studies on the ecology of roads and their detrimental impacts on wildlife and natural environments have been primarily conducted in Europe and North America, and few were performed in Asian countries (Kaszta et al., 2019, 2020; Silva et al., 2020). Over the past three decades, the road network in Iran has developed rapidly (Mohammadi et al., 2018). The study of landscape fragmentation due to construction of roads has a long history in many countries, but research in this field has only recently begun in Iran (Mohammadi and Kaboli, 2016; Moqanaki and Cushman, 2017; Mohammadi et al., 2018, 2021a; Parchizadeh et al., 2018; Mehdipour et al., 2019). Unfortunately, the expansion of the road network in Iran, particularly within protected areas, has been rapid and mostly without regard for the basic principles of conservation (Mohammadi and Kaboli, 2016; Mohammadi et al., 2018). This fact has caused an increasing number of wildlife-vehicle collisions, jeopardizing the survival of several species. For instance, endangered species such as the Asiatic cheetah (Acinonyx jubatus venaticus), the Persian leopard (Panthera pardus saxicolor) and, the Persian onager (Equus hemionus onager) are seriously threatened by roads in Iran (Farhadinia et al., 2013; Moqanaki and Cushman, 2017; Mohammadi et al., 2018, 2021b). Moreover, an investigation in the Hyrcanian forests of Iran showed that the growth of some of the native species, such as Carex buxbaumii, C. hordeistichos, Galium triflorum, Geum urbanum, Hypericum androsaemum, Primula vulgaris, and
Solanum kieseritzky was suppressed by the road construction, and hence, their percent cover was lowered significantly (Tarvirdizadeh et al., 2014).

To assess how ecological processes and biodiversity are affected, it is essential to collect information on landscape characteristics such as connectivity, habitat amount, potential fragmentation, and loss of habitat (Cushman, 2006). As a result, use of quantitative methods enhances current approaches to environmental assessment of the effects of landscape degradation (Karlson and Mörtberg, 2015; Kaszta et al., 2019, 2020).

The construction of the Isfahan-Shiraz highway (from central to southwestern Iran) began in early 2010s. The highway was originally due to open by 2019, but its opening was delayed and is now expected to be completed by the end of summer 2021. Along its total length of $225 \mathrm{~km}$, the highway passes through natural habitats and protected areas, potentially exerting adverse effects on its surrounding environments. Therefore, evaluating the potential impacts of this road on landscapes and proposing guidelines for conservation and planning strategies is crucial for rapid assessment of landscape and mitigation of negative effects on both the ecological and sociological resources.

Here, we aim to analyze the relationship between the construction of the highway and landscape fragmentation in southern Iran by addressing the following objectives: (1) to measure the fragmentation caused by this highway for different land cover types, and (2) to compare and contrast the current fragmentation levels of the landscape and different land cover types in the absence and presence of the road.

\section{MATERIALS AND METHODS}

\section{Study Area}

The Isfahan-Shiraz highway connects Isfahan (capital of Isfahan province in central Iran) to Shiraz (capital of Fars province in southern Iran) and runs south for $323 \mathrm{~km}$ (Figure 1). Along its length of $210 \mathrm{~km}$, the highway is joined with Samirom, Yasouj, and Takht-e Jamshid roadways through a series of connector roads (Figures 1-3). The width of the highway is $30 \mathrm{~m}$. The highway is in close vicinity of the Tang-e Bostanak Protected Area, a sensitive area under protection by the Department of Environment of Iran, and $8 \mathrm{~km}$ of the highway passes through this protected area. The Tang-e Bostanak Protected Area was designated as a protected area under Enactment 194 of Iran's High Council for the Environment on January 5th, 2000. The Protected Area covers 14,960 ha and is mostly covered by forest and montane vegetation. Its mean elevation ranges between 1,700 and 3,700 $\mathrm{m}$ above sea level. The region has an Irano-Turanian climate with dry summers and very cold winters with snowfall and freezing temperatures. Mean temperature in the region is 14$16^{\circ} \mathrm{C}$, and mean annual precipitation is $479.42 \mathrm{~mm}$. The area's major mammal fauna includes brown bear (Ursus arctos), Persian leopard (Panthera pardus saxicolor), gray wolf (Canis lupus), red fox (Vulpes vulpes), golden jackal (Canis auerus), wild cat (Felis lybica), striped hyaena (Hyaena hyaena), European badger (Meles meles), and wild goat (Capra aegagrus; Darvishsefat, 2006). 


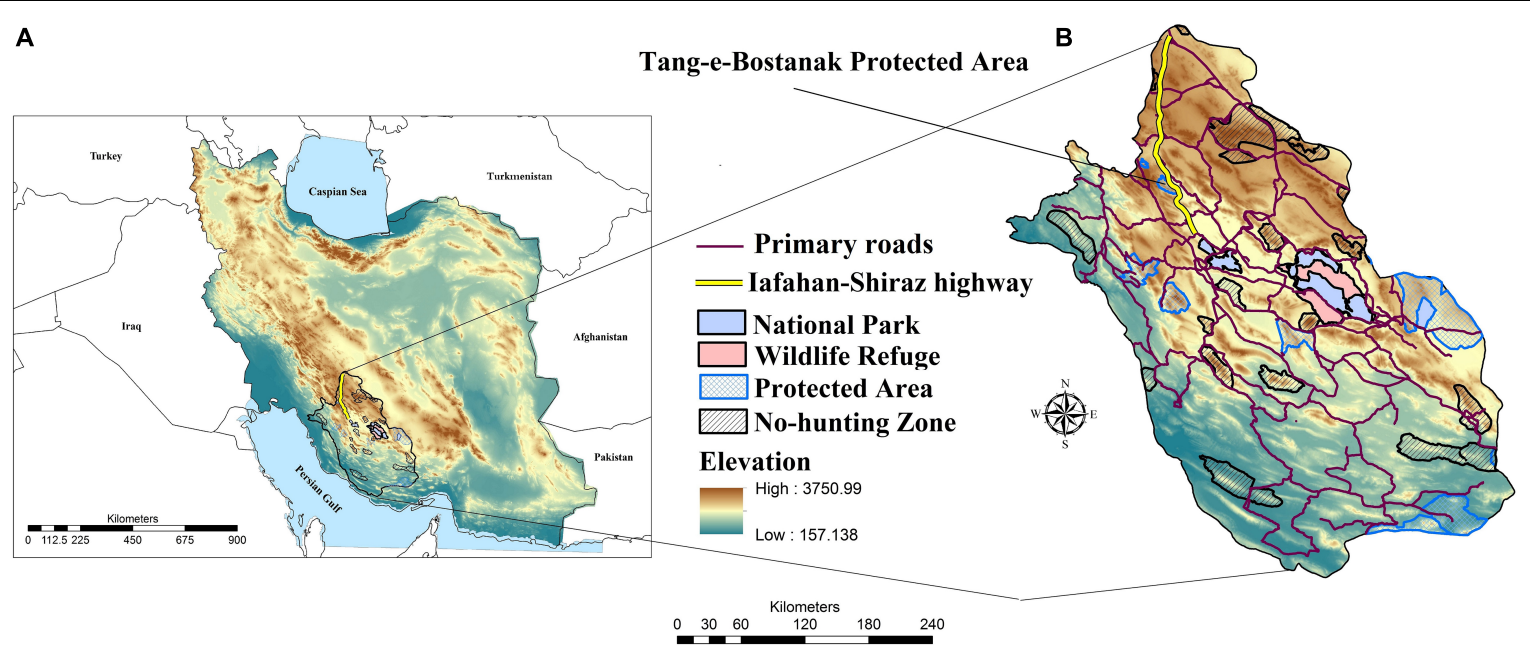

FIGURE 1 | Geographical location of the Isfahan-Shiraz highway and protected areas in Iran (A) and Fars province (B).

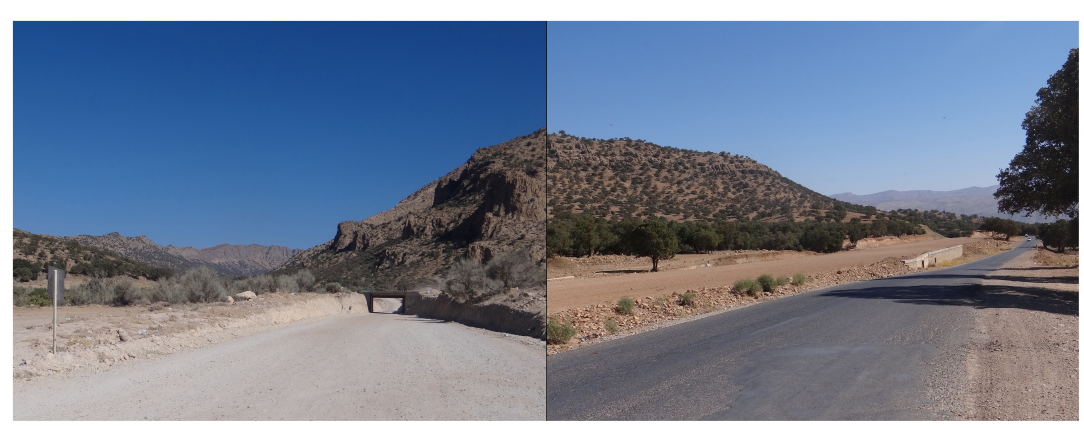

FIGURE 2 | Sections of the highway passing through the Tang-e-Bostanak Protected Area.

\section{Ecological Impacts of the Highway on Protected Areas, Forest and Rangeland Land Cover}

We used the land cover map of Iran created by the Iranian Forests, Range and Watershed Management Organization. This map was based on the maximum likelihood classification of Landsat 8 satellite images at $30 \mathrm{~m}$ resolution mainly from 2018. We extracted forests and rangelands from the land cover map for further analysis. Also, the most recent shapefiles of Iran's conservation network including national parks, protected areas, wildlife refuges, and no-hunting zones were used. In this study, landscape fragmentation and the ecological impacts of the highway on protected areas, forest cover, and rangeland cover were separately evaluated under conditions of presence and absence of the highway. The area affected by the IsfahanShiraz highway was identified as a 1,000-m buffer around the road (Forman and Alexander, 1998), which was then overlaid on maps of protected areas, rangeland and forest land covers in ArcGIS 10.4. Landscape metrics were calculated for the landscape under conditions of presence and absence of the highway in FRAGSTAT 3.3 (McGarigal and Cushman, 2002). The following seven metrics were used to evaluate structural changes: class area (CA), number of patches (NP), largest patch index (LPI), edge density (ED), landscape shape index (LSI), mean patch size (MPS), and patch cohesion (COHESION; Table 1). Landscape fragmentation and the ecological impacts of the highway were evaluated using effective mesh size (MESH), division index (DIVISION), and splitting index (SPLIT; Table 1).

\section{RESULTS}

\section{Degradation of Forest Habitats}

The results showed that in the absence of the highway (natural conditions) the CA metric for forest is equal to $537,195.6 \mathrm{ha}$, which will decrease to $530,788.7$ ha after the construction of the highway as $6,406.9$ ha $(1.19 \%)$ of forest habitat will be destroyed (Table 2). The number of forest habitat patches will increase from 34 to 35 following the completion of the highway (Table 2). LPI will fall from 15 to 10 , meaning the construction of the highway will reduce the size of the largest forest patch by $30 \%$. After construction of the highway, ED will increase to $1.38 \mathrm{~m}$ (from $1.36 \mathrm{~m}$ prior to construction), reflecting an increase in edge length in forest habitat patches (Table 2). LSI is 10.33 in the 


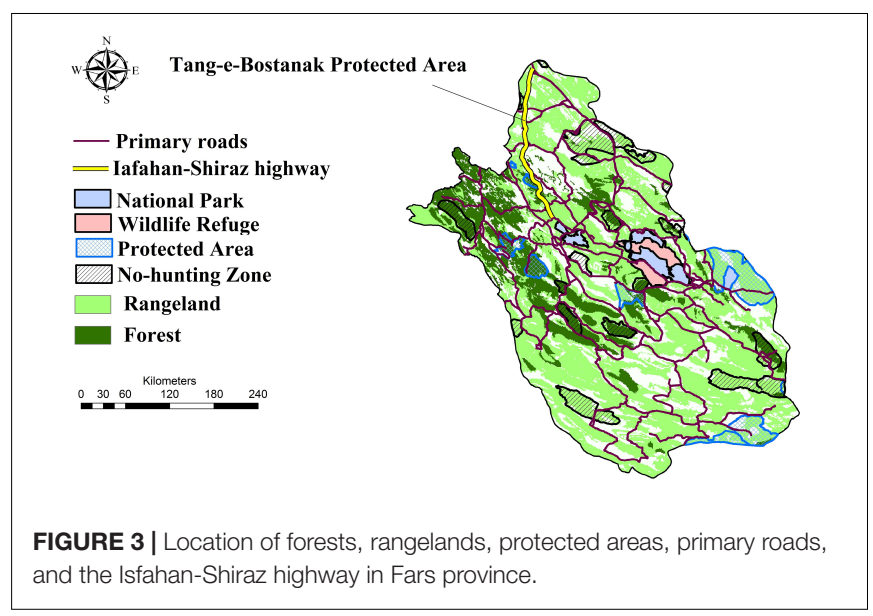

absence of the highway, but will reach 10.56 when the highway is built (Table 2).

In the absence of the highway, MPS is 15,799 ha, which will reduce to 15,165 ha after the construction of the highway (Table 2). The 634 ha (4.01\%) decrease in MPS represents a significant decrease in the core area of patches and an increase in edge length, which lowers the ecological and conservation value of forest patches. COHESION (measured in percent) represents the continuity and physical connection between forest patches in the landscape. The results showed that under natural conditions, the cohesion of the forest landscape in our study area is $98 \%$, which will decrease to $97 \%$ after the construction of the highway, indicating lowered cohesion of the forest landscape and hampered physical connection between forest patches (Table 2).

\section{Fragmentation by the Highway in the Forest Landscape}

The results showed that the effective MESH is 50,024 ha in the absence of the highway, and 29,487 ha in the presence of the highway (Table 2). The 20,537 ha decrease (41\%) is a substantial reduction, indicating a large increase in fragmentation in the forest landscape as the highway has separated forest habitat patches by $40 \%$. The SPLIT also rose from 40 under natural conditions to 68 after the construction of the highway (Table 2), representing a $70 \%$ increase in fragmentation. Although the DIVISION was high to begin with, the highway will further aggravate the conditions, elevating this metric to 0.98 (Table 2). This increase illustrates a decrease in the size of forest habitat patches, which in turn decreases the likelihood of wildlife being present in the patches.

\section{Degradation of Rangeland Habitats}

The results showed that CA of rangeland habitat is 934,643.7 ha under natural conditions, which will decline after the construction of the highway and reach 917,996.6 ha, representing a $16,647.1$ ha $(1.78 \%)$ loss in rangeland habitats (Table 2 ). The number of rangeland habitat patches will increase from 35 to 38 (Table 2). Moreover, LPI will decrease by 4 (from 34 to 30), indicating that the construction of the highway will shrink the largest patch by $4 \%$, therefore increasing edge length (Table 2 ).
TABLE 1 | Metrics used for the analysis of fragmentation and degradation of protected areas, rangeland, and forest land covers.

\begin{tabular}{|c|c|c|}
\hline $\begin{array}{l}\text { Landscape } \\
\text { metric }\end{array}$ & Abbreviation & Definition \\
\hline Class area & CA & $\begin{array}{l}\text { This metric is a subset of area, density, and edge } \\
\text { metrics. For evaluating land use change, this metric } \\
\text { is calculated at the level of land use classes in } \\
\text { hectares. CA shows the total area of patches } \\
\text { belonging to a particular class or category. }\end{array}$ \\
\hline $\begin{array}{l}\text { Number of } \\
\text { patches }\end{array}$ & NP & $\begin{array}{l}\text { This metric is a subset of area, density, and edge } \\
\text { metrics. For evaluating land use change, this } \\
\text { unitless metric is calculated at the level of land use } \\
\text { classes. NP is an index of habitat fragmentation. }\end{array}$ \\
\hline $\begin{array}{l}\text { Largest patch } \\
\text { index }\end{array}$ & LPI & $\begin{array}{l}\text { The ratio of the area of the largest patch to the total } \\
\text { area of the landscape. }\end{array}$ \\
\hline Edge density & ED & $\begin{array}{l}\text { This metric indicates the ratio of edge length to total } \\
\text { area of the landscape, expressed as meters per } \\
\text { hectare. }\end{array}$ \\
\hline $\begin{array}{l}\text { Landscape } \\
\text { shape index }\end{array}$ & LSI & $\begin{array}{l}\text { This index is used to measure the structure of the } \\
\text { landscape. }\end{array}$ \\
\hline $\begin{array}{l}\text { Mean patch } \\
\text { size }\end{array}$ & MPS & $\begin{array}{l}\text { This metric is a subset of the isolation-proximity } \\
\text { metric. It is calculated at the level of landscape in } \\
\text { meters. MPS calculates the shortest distance } \\
\text { between a patch and another patch of similar type. }\end{array}$ \\
\hline $\begin{array}{l}\text { Patch } \\
\text { cohesion } \\
\text { index }\end{array}$ & COHESION & $\begin{array}{l}\text { Based on the measurements of patch area and } \\
\text { perimeter, this metric calculates the cohesion } \\
\text { between patches within a particular category (class) } \\
\text { in the landscape. }\end{array}$ \\
\hline Division index & DIVISION & $\begin{array}{l}\text { This metric indicates the degree or extent of } \\
\text { division of patches into smaller patches, or the } \\
\text { decrease in the size of patches. }\end{array}$ \\
\hline $\begin{array}{l}\text { Splitting } \\
\text { index }\end{array}$ & SPLIT & $\begin{array}{l}\text { This metric indicates the fragmentation of protected } \\
\text { areas. }\end{array}$ \\
\hline $\begin{array}{l}\text { Effective } \\
\text { mesh size }\end{array}$ & MESH & $\begin{array}{l}\text { This metric indicates the probability of two points in } \\
\text { the landscape being linked (i.e., not disconnected } \\
\text { by barriers such as roads) }\end{array}$ \\
\hline
\end{tabular}

Edge density will increase from 1.77 to $1.85 \mathrm{~m}$ following the construction of the highway (Table 2), which indicates an increase in edge length in rangeland patches. In the absence of the highway, LSI is 10.99 , while it increases to 11.55 in the presence of the highway, signifying increased disruption in rangeland patches (Table 2). MPS of rangeland patches is 26,704 ha under natural conditions, which will decrease by 2,546 ha after the construction of the highway and reach 24,157 (24.15\%). This decrease will lead to a reduction in the core area of habitat patches and lower their conservation and ecological value. COHESION in the rangeland landscape was approximately 99\% before the highway was built, but will decrease to $98 \%$ afterward (Table 2). This decline illustrates lowered cohesion of the rangeland landscape and reduced connectivity between patches (Table 2).

\section{Fragmentation by the Highway in the Rangeland Landscape}

In the absence of the highway, MESH is 245,577 ha, which will experience a dramatic decline and drop to 196,428 ha following the construction of the highway. This 49,149 ha decrease is a remarkable reduction, indicating a large increase in fragmentation in the rangeland landscape as the highway severs 
TABLE 2 | Assessing habitat degradation and fragmentation of the forest and range land cover before and after construction of the Isfahan-Shiraz highway.

\begin{tabular}{|c|c|c|c|c|c|c|c|c|c|c|c|}
\hline \multirow{2}{*}{$\begin{array}{l}\text { Land } \\
\text { cover }\end{array}$} & \multirow[t]{2}{*}{ Metrics } & \multicolumn{7}{|c|}{ Structural changes } & \multicolumn{3}{|c|}{ Ecological impacts } \\
\hline & & $\begin{array}{c}\text { Class area } \\
\text { (CA) }\end{array}$ & $\begin{array}{c}\text { Number of } \\
\text { patches (NP) }\end{array}$ & $\begin{array}{l}\text { Largest } \\
\text { patch index } \\
\text { (LPI) }\end{array}$ & $\begin{array}{l}\text { Edge density } \\
\text { (ED) }\end{array}$ & $\begin{array}{l}\text { Landscape } \\
\text { shape index } \\
\text { (LSI) }\end{array}$ & $\begin{array}{l}\text { Mean patch } \\
\text { size (MPS) }\end{array}$ & $\begin{array}{c}\text { Patch } \\
\text { cohesion } \\
\text { index } \\
\text { (COHESION) }\end{array}$ & $\begin{array}{c}\text { Division } \\
\text { index } \\
\text { (DIVISION) }\end{array}$ & $\begin{array}{l}\text { Splitting } \\
\text { index } \\
\text { (SPLIT) }\end{array}$ & $\begin{array}{c}\text { Effective } \\
\text { mesh size } \\
\text { (MESH) }\end{array}$ \\
\hline \multirow[t]{2}{*}{ Forest } & Absence & $537,195.6$ & 34 & 15.06 & 1.36 & 10.33 & $15,799.87$ & 98.22 & 0.975 & 40.51 & $50,024.34$ \\
\hline & Presence & $530,788.7$ & 35 & 10.27 & 1.38 & 10.56 & $15,165.39$ & 97.65 & 0.985 & 68.72 & $29,487.61$ \\
\hline \multirow{2}{*}{$\begin{array}{l}\text { Range } \\
\text { land }\end{array}$} & Absence & $934,634.7$ & 35 & 34.46 & 1.77 & 10.99 & $26,704.11$ & 99.07 & 0.878 & 8.25 & 245,577 \\
\hline & Presence & $917,996.6$ & 38 & 30.6 & 1.85 & 11.55 & $24,157.81$ & 98.91 & 0.903 & 10.31 & $196,428.3$ \\
\hline
\end{tabular}

rangeland habitat (20\% increase in MESH value). SPLIT is 8.2 before the construction of the highway, but will increase to 10.3 afterward (Table 2). The 25\% increase in SPLIT also indicates a large increase in fragmentation compared to the conditions prior to the highway construction. The DIVISION metric was 0.87 before the construction of the highway, but will rise to 0.90 after the highway is constructed (Table 2), reflecting a decrease in the size of rangeland habitat patches.

\section{Degradation of Protected Areas}

The CA for the Tang-e Bostanak Protected Area is 14,960.02 ha before the construction of the highway, but roughly 912 (6.09\%) ha of the protected area will be lost after the construction of the highway, bringing CA down to $14,048.89$ ha (Table 3).

Largest patch index changes from 83.65 to 83.34 after construction of the highway, indicating a $0.41 \%$ reduction in the area of the Tang-e Bostanak Protected Area habitat patch, which will in turn increase edge length (Table 3 ). Total edge (TE) length was $8,976,570 \mathrm{~m}$ prior to the construction of the highway, increasing to 9,241,860 (2.3\%) $\mathrm{m}$ afterward. The 265,290 $\mathrm{m}$ increase in TE reflects an increase in edge length in the Tang-e Bostanak Protected Area (Table 3).

Landscape shape index is 8.3 under natural conditions, but will increase to 8.5 after the highway is constructed (Table 3). This change represents increased disturbance in protected areas, deteriorating ecological conditions, and lowered conservation value. Under natural conditions, COHESION is $99.78 \%$, which will decrease to $99.76 \%$ after the highway is constructed (Table 3). This reduction indicates decreased landscape continuity and integrity, and reduced physical connectivity between protected areas.

\section{Fragmentation by the Highway in Protected Areas}

Before the construction of the highway, MESH is $8,101,776$ ha for protected areas; however, this metric will reduce to $8,029,954$ ha after the highway is constructed. A 71,822 ha (1\%) reduction in $\mathrm{MESH}$ shows the increased fragmentation and loss of protected areas as a result of the highway construction (Table 3). The SPLIT will increase from 1.16 under natural conditions to 1.17 after construction of the highway (Table 3 ). This small increase means that the highway has worsened fragmentation of protected areas compared to natural conditions. The DIVISION is 0.29 in the absence of the highway, but will increase to 0.30 afterward (Table 3), reflecting a decrease in the size of protected areas.

\section{DISCUSSION}

Based on our results, the detrimental effects of the construction of the highway will inevitably result in multi-faceted consequences for the environment and its components in the study area. Roads and highways pose barriers to movement of a broad range of animals (Forman et al., 2003; Shepard et al., 2008). In addition, they are associated with elevated mortality caused by vehicle collisions and by providing access to humans for hunting, poaching and other forms of disruption (e.g., Kaszta et al., 2019, 2020). The results of the spatial ecological effects of the highway on natural habitats showed that forest and rangeland habitat types are of highest biodiversity value in our study area and are most exposed to road effects. Our findings are consistent with the results of Freitas et al. (2010) who indicated that road network density had the strongest relationship with deforestation and forest fragmentation. Similarly, Laurance et al. (2009) found that roads can have an array of deleterious effects on tropical forests and their associated wildlife. Nagendra et al. (2003) also highlighted the role of roads in causing deforestation. Areas closer to roads located at lower elevations were predominantly covered by agricultural land and were more severely fragmented, while areas further away from roads located at higher elevations were dominated by forests and were less fragmented.

Fars province has experienced significant population growth and industrial development over the past few decades owing to its hospitable weather and strategic geographical location as the transit corridor of southern Iran (Ministry of Economic Affairs and Finance, 2018). Both provinces of Fars and Isfahan encompass areas with high-value wildlife habitats which have considerable potential as future protected areas. The study area, in particular, contains outstanding habitats and is home to important species of conservation value; at the same time, the landscape is extensively fragmented by linear infrastructures, forcing wild species to be hemmed in by roads.

The conflicts between road construction and environmental protection have motivated research on the subject, particularly in central Iran. For instance, Makki et al. (2013) used a 
TABLE 3 | Assessing habitat degradation and fragmentation of the Tang-e Bostanak Protected Area before and after construction of the Isfahan-Shiraz highway.

\begin{tabular}{|c|c|c|c|c|c|c|c|c|}
\hline \multirow[t]{2}{*}{ Metrics } & \multicolumn{5}{|c|}{ Structural changes } & \multicolumn{3}{|c|}{ Ecological impacts } \\
\hline & $\begin{array}{l}\text { Class area } \\
\text { (CA) }\end{array}$ & $\begin{array}{l}\text { Largest patch } \\
\text { index (LPI) }\end{array}$ & $\begin{array}{l}\text { Edge density } \\
\text { (ED) }\end{array}$ & $\begin{array}{l}\text { Landscape shape } \\
\text { index (LSI) }\end{array}$ & $\begin{array}{l}\text { Patch cohesion index } \\
\text { (COHESION) }\end{array}$ & $\begin{array}{l}\text { Division index } \\
\text { (DIVISION) }\end{array}$ & $\begin{array}{l}\text { Splitting index } \\
\text { (SPLIT) }\end{array}$ & $\begin{array}{l}\text { Effective mesh } \\
\text { size (MESH) }\end{array}$ \\
\hline Absence & $14,960.02$ & 83.65 & $8,976,570$ & 8.3 & 99.78 & 0.298 & 1.163 & $8,101,776$ \\
\hline Presence & $14,048.89$ & 83.34 & $9,241,860$ & 8.51 & 99.76 & 0.303 & 1.173 & $8,029,954$ \\
\hline
\end{tabular}

habitat evaluation procedure to investigate the effects of the Isfahan Western Bypass Road and showed that the roads will severely affect the Ghamishloo Wildlife Refuge through fragmentation. Furthermore, Mehdipour et al. (2019) found that the construction of roads has led to subdivision in the Ghamishloo National Park and Wildlife Refuge, as indicated by an increase in SPLIT and DIVISION and a decrease in MESH and LPI. Research on the effects of roads on landscape characteristics (Jaeger et al., 2008; Zebardast et al., 2011; Zomeni and Vogiatzakis, 2014) similarly found that roadinduced decrease in MESH and increase in SPLIT and DIVISION are indicative of increased fragmentation and pose a threat to species which require large areas to survive as smaller patches jeopardize their survival.

Overall, the results of the present study showed that construction of the Isfahan-Shiraz highway will lead to the degradation of forest and rangeland habitats, as well as the Tang-e Bostanak Protected Area. Our findings demonstrated that following the construction of the highway, destruction and fragmentation of ecosystems and, in turn, loss of biodiversity and wildlife habitat will likely increase. We found that the number of forest and rangeland patches will increase greatly after construction of the highway. According to the principles of landscape ecology, a larger NP in an ecosystem implies that the ecosystem is more fragmented (at a given extent of habitat; e.g., Wasserman et al., 2012). A large NP is indicative of splitting and loss of connectivity in a previously homogeneous landscape; therefore, an increase in the NP metric reveals fragmentation and loss of continuity in the habitat (McGarigal and Marks, 1995).

Based on our results, a considerable portion of the protected area will be affected by the construction of the highway. In many cases, the residual patches after highway construction would be too small to support animal species that require large habitat extents, particularly carnivores of this region (e.g., brown bear, Persian leopard, and striped hyena). These species are all associated with areas of low human footprint, and are negatively affected by roads. For instance, Mohammadi et al. (2021a) showed that most parts of the brown bear connectivity network are intersected by roads in Iran. They also found low overlap between protected areas and brown bear corridors/core habitats, suggesting that the existing network of protected areas may be inadequate for conservation of the species in Iran. In another research, Ahmadi et al. (2020) showed that the existing protected areas conserve only $32 \%$ of the suitable habitats for the Asiatic cheetah (Acinonyx Jubatus venaticus) and the Persian leopard in Iran. In addition, according to a study by Shahnaseri et al. (2019), nearly the entire core habitats and corridors identified for the golden jackal and the gray wolf in central Iran are impacted by roads.
Habitat suitability and landscape connectivity are among the main determinants of roadkill risk for wildlife species (Grilo et al., 2011; Kang et al., 2016; Fabrizio et al., 2019), such as the European badger (Fabrizio et al., 2019). Although considered a habitat generalist, several studies have highlighted the strong dependence of the European badger on forests (Huck et al., 2008; Fabrizio et al., 2019), making it highly vulnerable to forest loss and habitat fragmentation. Also, striped hyaenas in Iran are constantly threatened by road vehicle collisions (Tourani et al., 2014; Mohammadi et al., 2018), habitat destruction and land modification (Dadashi-Jourdehi et al., 2020). Road construction and habitat fragmentation coupled with water scarcity and the aridity of landscapes further reduce the suitable habitats for certain wildlife species in Iran, especially the wild goat.

Other research has also highlighted the role of roads in fragmentation of habitats and increasing vehicle-induced wildlife mortalities (Moqanaki and Cushman, 2017; Parchizadeh et al., 2018; Kaboodvandpour et al., 2021; Mohammadi et al., 2021b). The majority of conservation areas in Iran are surrounded by roads, making road collisions a serious threat for carnivores, especially in corridors. It is therefore vital to protect core habitats and corridors in order to sustain core populations of species and enable dispersal among populations in the face of various threats. In a fragmented landscape, the long-term persistence of species depends on demographic exchange and gene flow among subpopulations (Cushman et al., 2012; Reding et al., 2013). Thus, maintaining landscape connectivity has increasingly become a focus of conservation efforts, particularly for species with specific biological traits such as large body sizes, low densities, large home ranges, and slow growth rates (Di Minin et al., 2016). As a result, there is a need to identify spatial priorities for carnivore conservation while accounting for habitat connectivity.

Long-term species conservation depends on connectivity of populations in order to locally conserve populations and to secure their range shifts in response to future threats such as climate change (Ashrafzadeh et al., 2020; Khosravi et al., 2021) and land use change (Moqanaki and Cushman, 2017). Connectivity networks can help mitigate the negative effects of habitat loss and fragmentation (Cushman et al., 2014). Establishment of strictly protected areas is often politically challenging. Therefore, we strongly recommend the use of new less strictly protected areas, such as no-hunting zones, close to the Tang-e Bostanak Protected Area.

Mean patch size has decreased in forest and rangeland classes after construction of the highway. This reduction indicates a decrease in the core area of the patches and an increase in edge length, which will likely result in reduction of ecological and conservation value. Low MPS coupled with high NP reinforce that the landscape is fragmented and this fragmentation 
is increased by the highway. The patch cohesion index (COHESION) has similarly decreased in forest and rangeland land cover classes, which means the continuity and integrity of these land cover classes has suffered and the connectivity between patches has been adversely affected. The lowered cohesion can negatively affect the movement of wildlife, their range, and movement corridors, as well as impacting their reproductive and feeding behavior. The LPI index has also declined following the construction of the highway, which illustrates how this change in the landscape has shrunk larger patches, the final stage of habitat loss and fragmentation, which in turn has increased edge length in the forest and rangeland landscapes. Shrinkage of the landscape puts the habitat in a critical viability state (Cushman et al., 2010). This decrease in patch size, accompanied by the increase in edge habitats, jeopardizes the survival of wildlife due to a decrease in the size of core areas within patches.

Edge density also increased following the construction of the highway in forest and rangeland classes. An increase in this metric demonstrates a decrease in patch size, an increase in the raggedness of patches and an increase in DIVISION, in turn leading to the expansion of boundary habitats and greater fragmentation (Feng et al., 2021). The LSI has increased for both classes, a sign of increased disturbance in forest and rangeland patches, rugged patch shapes and alterations to their natural configuration, which increases landscape pattern fragmentation and lowers their conservation value.

Effective MESH has declined for forest and rangeland landscapes. The decrease in this metric reveals increased fragmentation; in other words, the highway will disconnect forest and rangeland habitat patches. In addition to the direct mortality risk through road-kill, the severance of connectivity between patches affects animals' feeding and reproductive behavior by reducing the ability of species to survive. The SPLIT for forest and rangeland classes will also increase after the highway is built, meaning that fragmentation will increase in these habitats. Fragmentation of a habitat into smaller patches is evidence of increased edge length. This has significant implications for the habitat and its biodiversity, which leads to reduced access to resources by wildlife and indicator species.

The DIVISION will increase following construction of the highway, due to increased fragmentation and larger NP, meaning the size of forest patches will decrease and the survival of species is threatened. In a similar work by Barati et al. (2017) in Kolah Ghazi National Park in central Iran, MPS increased between 1993 and 2003, indicative of consolidation of small patches and an increase in the size of patches, both contributing to reduced fragmentation and improved landscape integrity.

Jahani (2019) used NP, ED, and effective MESH to quantify fragmentation in Lar National Park and Varjin Protected Area in Iran. Their results showed that unpaved roads, agricultural activities, and dams were, respectively, the most significant factors influencing fragmentation in the habitats of the leopard, wild goat, and wild sheep in the study area. In Varjin Protected Area, agriculture was the most important factor affecting wildlife habitats. In our study, effective MESH also decreased in the protected area (Tang-e Bostanak Protected Area) after construction of the highway. Increased numbers of barriers within a landscape decrease the value of this metric, equivalent to reduced cohesion (Jahani, 2019).

\section{CONCLUSION}

Our aim was to study the impacts of the road network on its surrounding environment and nearby protected areas at the landscape level in southern Iran. We evaluated roadinduced fragmentation using a selection of landscape metrics. The findings highlighted that the construction of the IsfahanShiraz highway will cause substantial landscape fragmentation and dissection of the land within both the landscape at large and in the Tang-e Bostanak Protected Area. We suggest that indicator species which are harmed by the highway such as brown bear and Persian leopard be identified, and that their movement corridors be determined within the area affected by the highway based on monitoring and records of their presence. The remaining small patches should be protected owing to their ecological significance for connecting large patches. Furthermore, habitat corridors bisected by the highway can become hotspots of vehicle-wildlife collision in the future when construction of the highway is complete. As large-scale mitigation measures are less likely to address landscape-scale impacts of roads in Iran, it is necessary to employ practicable measures. Hence, at locations where ecological corridors used by indicator species overlap with the highway, passage structures (overpasses, underpasses, and water passage ways) should be built to reduce road mortality of wildlife (e.g., Cushman et al., 2014). In short, the findings of this study show that quantification of landscape patterns can help us understand the connections between human activities (such as road building) and changes in the landscape. The results strengthen the need to further explore the potential impacts of highway construction in or adjacent to sensitive habitats. These findings can also direct policy and planning toward sustainable development. Although our results were promising, further investigations employing a larger number of landscape metrics and other parameters such as configuration and patch isolation are required.

\section{DATA AVAILABILITY STATEMENT}

The original contributions presented in the study are included in the article/supplementary material, further inquiries can be directed to the corresponding author/s.

\section{AUTHOR CONTRIBUTIONS}

AM: conceptualized, methodology, formal analysis, and investigation. AM and FF: writing - orginal draft preparation, writing review, and editing.

\section{ACKNOWLEDGMENTS}

We are grateful to the personnel and officers at the Provincial Department of Environment of Fars for providing some of the information used in this study. 


\section{REFERENCES}

Ahmadi, M., Farhadinia, M. S., Cushman, S. A., Hemami, M. R., Nezami Balouchi, B., Jowkar, H., et al. (2020). Species and space: a combined gap analysis to guide management planning of conservation areas. Landsc. Ecol. 35, 1505-1517. doi: 10.1007/s10980-020-01033-5

Ali, R., Barra, A. F., Berg, C., Damania, R., Nash, J., and Russ, J. (2015). Highways to Success or Byways to Waste: Estimating the Economic Benefits of Roads in Africa. Washington, DC: The World Bank.

Ascensão, F., Yogui, D. R., Alves, M. H., Alves, A. C., Abra, F., and Desbiez, A. L. (2021). Preventing wildlife roadkill can offset mitigation investments in short-medium term. Biol. Conserv. 253:108902. doi: 10.1016/j.biocon.2020. 108902

Ashrafzadeh, M. R., Khosravi, R., Adibi, M. A., Taktehrani, A., Wan, H. Y., and Cushman, S. A. (2020). A multi-scale, multi-species approach for assessing effectiveness of habitat and connectivity conservation for endangered felids. Biol. Conserv. 245:108523. doi: 10.1016/j.biocon.2020.10 8523

Barati, B., Jahani, A., Zebardast, L., and Rayegani, B. (2017). Integration assessment of the protected areas using landscape ecological approach (Case study: Kolah Ghazy national park and wildlife refuge). Town Ctry. Plann. 9, 153-168. doi: 10.22059/jtcp.2017.61412

Borowik, T., Ratkiewicz, M., Maślanko, W., Kowalczyk, R., Duda, N., and Żmihorski, M. (2021). Temporal pattern of moose-vehicle collisions. Transp. Res. D Transp. Environ. 92:102715. doi: 10.1016/j.trd.2021.102715

Cao, F., Dan, L., Ma, Z., and Gao, T. (2021). The impact of land use and land cover change on regional climate over East Asia during 1980-2010 using a coupled model. Theor. Appl. Climatol. 145, 549-565. doi: 10.1038/s41598-020-59503-4

Carter, N., Killion, A., Easter, T., Brandt, J., and Ford, A. (2020). Road development in Asia: assessing the range-wide risks to tigers. Sci. Adv. 6:eaaz9619. doi: 10.1126/sciadv.aaz9619

Clevenger, A. P., Wierzchowski, J., Chruszcz, B., and Gunson, K. (2002). GISgenerated, expert-based models for identifying wildlife habitat linkages and planning mitigation passages. Conserv. Biol. 16, 503-514. doi: 10.1046/j.15231739.2002.00328.x

Cushman, S. A. (2006). Effects of habitat loss and fragmentation on amphibians: a review and prospectus. Biol. Conserv. 128, 231-240. doi: 10.1016/j.biocon.2005. 09.031

Cushman, S. A., Evans, J. S., and McGarigal, K. (2010). "Landscape ecology: past, present, and future," in Spatial Complexity, Informatics, and Wildlife Conservation, eds S. A. Cushman and F. Huettmann (Tokyo: Springer). doi: 10.1007/978-4-431-87771-4_4

Cushman, S. A., Lewis, J. S., and Landguth, E. L. (2014). Why did the bear cross the road? Comparing the performance of multiple resistance surfaces and connectivity modeling methods. Diversity 6, 844-854. doi: 10.3390/d6040844

Cushman, S. A., Shirk, A., and Landguth, E. L. (2012). Separating the effects of habitat area, fragmentation and matrix resistance on genetic differentiation in complex landscapes. Landsc. Ecol. 27, 369-380. doi: 10.1007/s10980-011-9 693-0

Dadashi-Jourdehi, A., Shams-Esfandabad, B., Ahmadi, A., Rezaei, H. R., and Toranj-Zar, H. (2020). Predicting the potential distribution of striped hyena Hyaena hyaena in Iran. Belg. J. Zool. 150, 185-195.

Darvishsefat, A. A. (2006). Atlas of Protected Areas of Iran. Tehran: University of Tehran.

Dean, W. R. J., Seymour, C. L., Joseph, G. S., and Foord, S. H. (2019). A review of the impacts of roads on wildlife in semi-arid regions. Diversity 11:81. doi: 10.3390/d11050081

Di Minin, E., Slotow, R., Hunter, L. T., Pouzols, F. M., Toivonen, T., Verburg, P. H., et al. (2016). Global priorities for national carnivore conservation under land use change. Sci. Rep. 6:23814. doi: 10.1038/srep23814

Dulac, J. (2013). Global Land Transport Infrastructure Requirements, Vol. 20. Paris: International Energy Agency, 2014.

Epps, C. W., Palsbøll, P. J., Wehausen, J. D., Roderick, G. K., Ramey, R. R., and McCullough, D. R. (2005). Highways block gene flow and cause a rapid decline in genetic diversity of desert bighorn sheep. Ecol. Lett. 8, 1029-1038. doi: 10.1111/j.1461-0248.2005.00804.x

Fabrizio, M., Di Febbraro, M., D’Amico, M., Frate, L., Roscioni, F., and Loy, A. (2019). Habitat suitability vs landscape connectivity determining roadkill risk at a regional scale: a case study on European badger (Meles meles). Eur. J. Wildl. Res. 65:7.

Farhadinia, M. S., Akbari, H., Mousavi, S. J., Eslami, M., Azizi, M., Shokouhi, J., et al. (2013). Exceptionally long movements of the Asiatic cheetah Acinonyx jubatus venaticus across multiple arid reserves in central Iran. Oryx 47, 427-430. doi: 10.1017/S0030605313000641

Feng, S., Liu, S., Jing, L., Zhu, Y., Yan, W., Jiang, B., et al. (2021). Quantification of the environmental impacts of highway construction using remote sensing approach. Remote Sens. 13:1340. doi: 10.3390/rs13071340

Forman, R. T., and Alexander, L. E. (1998). Roads and their major ecological effects. Annu. Rev. Ecol. Syst. 29, 207-231. doi: 10.1146/annurev.ecolsys.29.1.207

Forman, R. T. T., Sperling, D., Bissonette, J. A., Clevenger, A. P., Cutshall, C. D., Dale, V. H., et al. (2003). Road Ecology. Washington, DC: Island Press.

Freitas, S. R., Hawbaker, T. J., and Metzger, J. P. (2010). Effects of roads, topography, and land use on forest cover dynamics in the Brazilian Atlantic Forest. For. Ecol. Manag. 259, 410-417.

Fullman, T. J., Wilson, R. R., Joly, K., Gustine, D. D., Leonard, P., and Loya, W. M. (2021). Mapping potential effects of proposed roads on migratory connectivity for a highly mobile herbivore using circuit theory. Ecol. Appl. 31:e2207. doi: 10.1002/eap. 2207

Grilo, C., Ascensão, F., Santos-Reis, M., and Bissonette, J. A. (2011). Do wellconnected landscapes promote road-related mortality? Eur. J. Wildl. Res. 57, 707-716.

Huck, M., Davison, J., and Roper, T. J. (2008). Predicting European badger Meles meles sett distribution in urban environments. Wildl. Biol. 14, 188-198. doi: 10.2981/0909-6396(2008)14[188:pebmms]2.0.co;2

Ibisch, P. L., Hoffmann, M. T., Kreft, S., Pe’er, G., Kati, V., Biber-Freudenberger, L., et al. (2016). A global map of roadless areas and their conservation status. Science 354, 1423-1427. doi: 10.1126/science.aaf7166

Iglesias-Merchan, C., Horcajada-Sánchez, F., Diaz-Balteiro, L., Escribano-Ávila, G., Lara-Romero, C., Virgós, E., et al. (2018). A new large-scale index (AcED) for assessing traffic noise disturbance on wildlife: stress response in a roe deer (Capreolus capreolus) population. Environ. Monit. Assess. 190:185. doi: 10.1007/ s10661-018-6573-y

Jaeger, J. A., Bertiller, R., Schwick, C., Müller, K., Steinmeier, C., Ewald, K. C., et al. (2008). Implementing landscape fragmentation as an indicator in the Swiss Monitoring System of Sustainable Development (MONET). J. Environ. Manag. 88, 737-751. doi: 10.1016/j.jenvman.2007.03.043

Jahani, A. (2019). Integration assessment of protected rangeland habitats using landscape ecological approach. J. Plant Ecosyst. Conserv. 7, 1-20. doi: 10.22059/ JTCP.2017.61412

Kaboodvandpour, S., Almasieh, K., and Zamani, N. (2021). Habitat suitability and connectivity implications for the conservation of the Persian leopard along the Iran-Iraq border. Ecol. Evol. 11, 13464-13474.

Kang, W., Minor, E. S., Woo, D., Lee, D., and Park, C. R. (2016). Forest mammal roadkills as related to habitat connectivity in protected areas. Biodivers. Conserv. 25, 2673-2686

Karlson, M., and Mörtberg, U. (2015). A spatial ecological assessment of fragmentation and disturbance effects of the Swedish road network. Landsc. Urban Plann. 134, 53-65. doi: 10.1016/j.landurbplan.2014.10.009

Kaszta, Ż., Cushman, S. A., Hearn, A. J., Burnham, D., Macdonald, E. A., Goossens, B., et al. (2019). Integrating Sunda clouded leopard (Neofelis diardi) conservation into development and restoration planning in Sabah (Borneo). Biol. Conserv. 235, 63-76. doi: 10.1016/j.biocon.2019.04.001

Kaszta, Ż., Cushman, S. A., and Macdonald, D. W. (2020). Prioritizing habitat core areas and corridors for a large carnivore across its range. Anim. Conserv. 23, 607-616. doi: 10.1111/acv.12575

Khosravi, R., Hemami, M. R., Malakoutikhah, S., Ashrafzadeh, M. R., and Cushman, S. A. (2021). Prey availability modulates predicted range contraction of two large felids in response to changing climate. Biol. Conserv. 255:109018.

Kumar, M., Denis, D. M., Singh, S. K., Szabó, S., and Suryavanshi, S. (2018). Landscape metrics for assessment of land cover change and fragmentation of a heterogeneous watershed. Remote Sens. Appl. Soc. Environ. 10, 224-233.

Laurance, W. F., Campbell, M. J., Alamgir, M., and Mahmoud, M. I. (2017). Road expansion and the fate of Africa's tropical forests. Front. Ecol. Evol. 5:75. doi: $10.3389 /$ fevo.2017.00075

Laurance, W. F., Goosem, M., and Laurance, S. G. (2009). Impacts of roads and linear clearings on tropical forests. Trends Ecol. Evol. 24, 659-669. 
Leblond, M., Dussault, C., and Ouellet, J. P. (2013). Avoidance of roads by large herbivores and its relation to disturbance intensity. J. Zool. 289, 32-40. doi: 10.1111/j.1469-7998.2012.00959.x

Loraamm, R. W. (2011). Road-Based Landscape Metrics for Quantifying Habitat Fragmentation. Master's thesis. Tampa, FL: University of South Florida.

Makki, T., Fakheran, S., Moradi, H., Iravani, M., and Senn, J. (2013). Landscapescale impacts of transportation infrastructure on spatial dynamics of two vulnerable ungulate species in Ghamishloo wildlife refuge, Iran. Ecol. Indic. 31, 6-14. doi: 10.1016/j.ecolind.2013.03.001

Mansour, S., Al-Belushi, M., and Al-Awadhi, T. (2020). Monitoring land use and land cover changes in the mountainous cities of Oman using GIS and CA-Markov modelling techniques. Land Use Policy 91:104414.

McGarigal, K., and Cushman, S. (2005). "The gradient concept of landscape structure [Chapter 12]," in Issues and Perspectives in Landscape Ecology, eds J. A. Wiens and M. R. Moss (Cambridge: Cambridge University Press), 112-119.

McGarigal, K., and Cushman, S. A. (2002). Comparative evaluation of experimental approaches to the study of habitat fragmentation effects. Ecol. Appl. 12, 335345.

McGarigal, K., Cushman, S. A., and Ene, E. (2012). FRAGSTATS v4: Spatial Pattern Analysis Program for Categorical and Continuous Maps. Amherst, MA: University of Massachusetts.

McGarigal, K., and Marks, B. J. (1995). Spatial Pattern Analysis Program for Quantifying Landscape Structure. Gen. Tech. Rep. PNW-GTR-351. Portland, OR: US Department of Agriculture, Forest Service, Pacific Northwest Research Station, 1-122. doi: 10.2737/PNW-GTR-351

Mehdipour, N., Fakheran, S., Soffianian, A., and Pourmanafi, S. (2019). Roadinduced fragmentation and the environmental value of roadless areas in a partly protected landscape in Central Iran. Environ. Monit. Assess. 191:461. doi: 10.1007/s10661-019-7571-4

Meijer, J. R., Huijbregts, M. A., Schotten, K. C., and Schipper, A. M. (2018). Global patterns of current and future road infrastructure. Environ. Res. Lett. 13:064006. doi: $10.1088 / 1748-9326 /$ aabd42

Ministry of Economic Affairs and Finance (2018). Ministry of Economic Affairs and Finance-Islamic Republic of Iran. Available online at: http://irangov.ir/cat/505 (accessed February, 2021).

Mishra, P. K., Rai, A., and Rai, S. C. (2020). Land use and land cover change detection using geospatial techniques in the Sikkim Himalaya, India. Egypt. J. Remote Sens. Space Sci. 23, 133-143.

Mohammadi, A., Almasieh, K., Clevenger, A. P., Fatemizadeh, F., Rezaei, A., Jowkar, H., et al. (2018). Road expansion: a challenge to conservation of mammals, with particular emphasis on the endangered Asiatic cheetah in Iran. J. Nat. Conserv. 43, 8-18. doi: 10.1016/j.jnc.2018.02.011

Mohammadi, A., Almasieh, K., Nayeri, D., Ataei, F., Khani, A., López-Bao, J. V., et al. (2021a). Identifying priority core habitats and corridors for effective conservation of brown bears in Iran. Sci. Rep. 11:1044. doi: 10.1038/s41598020-79970-z

Mohammadi, A., Almasieh, K., Wan, H. Y., Nayeri, D., Alambeigi, A., Ransom, J. I., et al. (2021b). Integrating spatial analysis and questionnaire survey to better understand human-onager conflict in Southern Iran. Sci. Rep. 11:12423.

Mohammadi, A., and Kaboli, M. (2016). Evaluating wildlife-vehicle collision hotspots using kernel-based estimation: a focus on the endangered Asiatic cheetah in central Iran. Hum. Wildl. Interact. 10, 103-109. doi: 10.26077/0xjdaz08

Moqanaki, E. M., and Cushman, S. A. (2017). All roads lead to Iran: predicting landscape connectivity of the last stronghold for the critically endangered Asiatic cheetah. Anim. Conserv. 20, 29-41. doi: 10.1111/acv.12281

Nagendra, H., Southworth, J., and Tucker, C. (2003). Accessibility as a determinant of landscape transformation in western Honduras: linking pattern and process. Landsc. Ecol. 18, 141-158.

Ordiz, A., Sæbø, S., Kindberg, J., Swenson, J. E., and Støen, O. G. (2017). Seasonality and human disturbance alter brown bear activity patterns: implications for circumpolar carnivore conservation? Anim. Conserv. 20, 51-60. doi: 10.1111/ acv. 12284

Parchizadeh, J., Shilling, F., Gatta, M., Bencini, R., Qashqaei, A. T., Adibi, M. A., et al. (2018). Roads threaten Asiatic cheetahs in Iran. Curr. Biol. 28, R1141R1142. doi: 10.1016/j.cub.2018.09.005

Parsa, V. A., Yavari, A., and Nejadi, A. (2016). Spatio-temporal analysis of land use/land cover pattern changes in Arasbaran Biosphere Reserve: Iran. Model. Earth Syst. Environ. 2, 1-13.
Reding, D. M., Cushman, S. A., Gosselink, T. E., and Clark, W. R. (2013). Linking movement behavior and fine-scale genetic structure to model landscape connectivity for bobcats (Lynx rufus). Landsc. Ecol. 28, 471-486.

Ruiz, A., and Guevara, J. (2020). Environmental and economic impacts of road infrastructure development: dynamic considerations and policies. J. Manage. Eng. 36:04020006. doi: 10.3390/environments6060072

Saint-Andrieux, C., Calenge, C., and Bonenfant, C. (2020). Comparison of environmental, biological and anthropogenic causes of wildlife-vehicle collisions among three large herbivore species. Popul. Ecol. 62, 64-79. doi: 10.1002/1438-390X.12029

Shahnaseri, G., Hemami, M. R., Khosravi, R., Malakoutikhah, S., Omidi, M., and Cushman, S. A. (2019). Contrasting use of habitat, landscape elements, and corridors by grey wolf and golden jackal in central Iran. Landsc. Ecol. 34, 1263-1277.

Shepard, D. B., Kuhns, A. R., Dreslik, M. J., and Phillips, C. A. (2008). Roads as barriers to animal movement in fragmented landscapes. Anim. Conserv. 11, 288-296. doi: 10.1111/j.1469-1795.2008.00183.x

Shooshtari, S. H., Hosseini, S. M., Esmaili-Sari, A., and Gholamalifard, M. (2012). Monitoring land cover change, degradation, and restoration of the Hyrcanian forests in northern Iran (1977-2010). Int. J. Environ. Sci. 3, 1038-1056.

Silva, I., Crane, M., and Savini, T. (2020). High roadkill rates in the Dong PhayayenKhao Yai World Heritage Site: conservation implications of a rising threat to wildlife. Anim. Conserv. 23, 466-478.

Singh, S. K., Srivastava, P. K., Szabó, S., Petropoulos, G. P., Gupta, M., and Islam, T. (2017). Landscape transform and spatial metrics for mapping spatiotemporal land cover dynamics using Earth Observation data-sets. Geocarto Int. 32, 113-127.

Tarvirdizadeh, H., Nikooy, M., Pourbabaei, H., and Naghdi, R. (2014). Effects of road construction on biodiversity and composition of herbaceous species cover, Asalem forest, northern Iran. For. Ideas 20, 157-169.

Tourani, M., Moqanaki, E. M., Boitani, L., and Ciucci, P. (2014). Anthropogenic effects on the feeding habits of wolves in an altered arid landscape of central Iran. Mammalia 78, 117-121.

Turner, M. G., Pearson, S. M., Bolstad, P., and Wear, D. N. (2003). Effects of land-cover change on spatial pattern of forest communities in the Southern Appalachian Mountains (USA). Landsc. Ecol. 18, 449-464.

Valerio, F., Basile, M., and Balestrieri, R. (2021). The identification of wildlifevehicle collision hotspots: citizen science reveals spatial and temporal patterns. Ecol. Process. 10:6.

Wasserman, T. N., Cushman, S. A., Shirk, A. S., Landguth, E. L., and Littell, J. S. (2012). Simulating the effects of climate change on population connectivity of American marten (Martes americana) in the northern Rocky Mountains, USA. Landsc. Ecol. 27, 211-225.

Zebardast, L., Yavari, A. R., Salehi, E., and Makhdoum, M. (2011). Application of effective mesh size metric for the analysis of forest habitat fragmentation inside the defined road effect zone of Golestan National Park. J. Environ. Stud. 37, $15-20$.

Zhao, S., Peng, C., Jiang, H., Tian, D., Lei, X., and Zhou, X. (2006). Land use change in Asia and the ecological consequences. Ecol. Res. 21, 890-896.

Zomeni, M., and Vogiatzakis, I. N. (2014). Roads and roadless areas in Cyprus: implications for the Natura 2000 network. J. Landsc. Ecol. 7, $75-90$.

Conflict of Interest: The authors declare that the research was conducted in the absence of any commercial or financial relationships that could be construed as a potential conflict of interest.

Publisher's Note: All claims expressed in this article are solely those of the authors and do not necessarily represent those of their affiliated organizations, or those of the publisher, the editors and the reviewers. Any product that may be evaluated in this article, or claim that may be made by its manufacturer, is not guaranteed or endorsed by the publisher.

Copyright (c) 2021 Mohammadi and Fatemizadeh. This is an open-access article distributed under the terms of the Creative Commons Attribution License (CC BY). The use, distribution or reproduction in other forums is permitted, provided the original author(s) and the copyright owner(s) are credited and that the original publication in this journal is cited, in accordance with accepted academic practice. No use, distribution or reproduction is permitted which does not comply with these terms. 